\title{
PENELITIAN PENDAHULUAN PENGOLAHAN AIR LIMBAH SECARA AEROBIK
}

oleh :

\author{
Ir. Aida Soelaeman *)
}

\begin{abstract}
:
Aerobic treatment is used for treatment of waste water which is of a relatively low concentration and is in large quantity as well. In this treatment, domestic waste water seeks to purify, by making maximum used of bacteria's ability to take in organic matters. The COD removal from this research are describe that concentration of COD already reached $\pm 90 \%$.
\end{abstract}

\section{PENDAHULUAN.}

Karena limbah industri pada umumnya mengandung zat -zat organik yang aktip tinggi yang mana ini dapat menyebabkan bau busuk, juga dapat menyebabkan turunnya kadar oksigen terlarut dari badan air yang dilaluinya maka perlu diadakan pengolahan air limbah industri yang mengandung zat-zat organik tersebut sampai air limbah tersebut memenuhi standar untuk dibuang ke perairan.

Ruang Lingkup Pembahasan.

Untuk mengelola air limbah secara baik diperlukan pengetahuan dari beberapa parameter yang bersangkutan dalam menangani air limbah. Adapun pengetahuan dalam pengolahan air limbah meliputi B.O.D, C.O.D, pH M.L.S.S, BOD/COD load, logam-logam berat dan sebagainya. Sesuai dengan judul Buletin ini, yaitu Penelitian Pendahuluan Pengolahan Air Limbah Secara Aerobik, maka buletin ini berisikan tentang bagaimana sebaiknya suatu industri mengelola air limbahnya secara aerobik, yang selanjutnya dapat dikembangkan cara pengolahan air limbah tersebut dilapangan.

*) Staf Peneliti

Balai Lit. Kimia Organik \& Fermentasi

Balai Besar Industri Kimia

\section{TINJAUAN PUSTAKA.}

A. Beberapa istilah yang sering diperguna kan pada pengolahan air limbah.

Air limbah (waste water), adalah kotoran dari masyarakat yang dapat berasal dari kotoran rumah tangga dan juga dapat berasal dari industri, serta buangan lainnya. Dengan demikian air buangan ini merupakan hal yang bersifat kotoran umum.

INFLUEN, adalah yang beraal dari proses produksi yang selanjutnya mengalir kesuatu unit pengolahan air limbah secara keseluruhan.

EFFLUENT, adalah air yang keluar dari salah satu unit pengolah air limbah secara keseluruhan.

T.S.S. (Total Suspended Solid), adalah jumlah berat dalam milligram/liter $(\mathrm{mg} / \mathrm{l})$ dari lumpur kering yang ada didalam air limbah setelah mengalami penyaringan dengan membran.

MLSS (Miled Liquor Suspended Solid), adalah jumlah TSS yang berasal dari unit pengendapan lumpur aktif.

COD/BOD load, adalah banyaknya zat organik/mikroorganisme (bakteri) yang terkandung dalam bak aerasi atau besar nya beban zat organik/mikroorganisme (bakteri) yang terkandung dalam MLSS. 
B. Parameter-Parameter Yang Berhubung an Dengan Air Limbah, antara lain :

\section{Temperatur:}

Air limbah yang telah mengalami perlaku an harus memenuhi persyaratan temperatur sebelum dibebaskan kelingkungan, karena makhluk air memiliki temperatur optimum untuk kelangsungan hidupnya.

\section{Kekeruhan :}

Kekeruhan yang terkandung dalam air limbah akan menghambat penembusan cahaya sinar ultra violet dari matahari yang mana dibutuhkan oleh mikroorganis me dan phytoplankton untuk reaksi foto sintesa yang menghasilkan oksigen. Jika reaksi fotosintesa terhambat, maka penambahan oksigen terlarut akan tidak berlangsung secara maksimal dan jumlah phytoplankton akan menurun.

\section{Warna :}

Limbah cair yang berwarna akan meningkatkan warna badan air yang menerima limbah cair tersebut, jika air limbah langsung dibuang kelingkungan. Badan air yang berwarna dapat dapat menyerap berbagai panjang gelombang cahaya matahari, sehingga intensitas cahaya yang diperlukan untuk reaksi fotosintesa akan menurun.

\section{Oksigen Terlarut (Dissolved Oxygen,} D.O.) :

Kelarutan oksigen dipengaruhi oleh temperatur, kelarutan oksigen dalam air adalah tinggi, pada temperatur yang rendah dan sebaliknya D.O. yang tinggi di badan air harus dipertahankan untuk kelangsungan hidup biøta air.

\section{Biochemical Oxygen Demand (BOD)} Limbah cair industri umumnya mengan dung senyawa organik. Senyawa organik ini dibagi menjadi :

a. Senyawa organik yang dapat diuraikan oleh mikroorganisme melalui proses oksidasi biokimia (biodegradable organic substances). b. Senyawa organik yang tidak dapat diuraikan oleh mikroorganisme.

Parameter BOD ini adalah parameter yang digunakan untuk tolok ukur kandunngan senyawa organik yang dapat diuraikan oleh mikroorganisme. Tolok ukur ini dipilih karena kebutuhan oksigen untuk reaksi yang dilakukan oleh sel ini setara dengan konsentrasi senyawa organic yang diuraikan.

\section{Chemical Oxygen Demand (COD) :}

Senyawa organik masih banyak yang tidak dapat dimanfaatkan atau tidak dapat diuraikan oleh mikroorganisme dalam perairan alami. Senyawa-senyawa ini dinyatakan sebagai tolok ukur yang lain untuk menyatakan kebutuhan oksigen yang diperlukan pada reaksi oksidasi secara kimiawi. Kebutuhan oksigen untuk reaksi ini dinyatakan sebagai Chemical Oxygen Demand (COD). Nilai COD ini mencakup kebutuhan oksigen untuk reaksi biokimiaawi, karena senyawa organik yang dapat diuraikan oleh mikroorganisme dapat pula mengalami oksidasi melalui reaksi kimiawi, jadi nilai COD dari suatu hasil analisa cuplikan akan selalu memiliki nilai numerik yang lebih besar daripada nilai BOD.

\section{PROSES PENGOLAHAN AIR LIM- BAH.}

Upaya penurunan kadar limbah yang terkandung dalam air dapat dilakukan dengan penerapan suatu sistim perlakuan limbah yang didasarkan atas perkiraan sifat-sifat limbah cair tersebut. Sistim perlakuan terhadap limbah cair dapat dilakukan sebagai berikut (lihat tabel 1).
a. Perlakuan awal/primer
b. Perlakuan sekunder
c. Perlakuan tersier
d. Perlakuan lumpur. 
Tabel 1 : Satuan proses dan operasi dari kelompok perlakuan.

\begin{tabular}{|c|c|c|}
\hline Kelompok & Satuan Proses dan Satuan Operasi & \\
\hline Perlakuan awal & $\begin{array}{l}\text { Penyaringan serpihan } \\
\text { Pemisahan padatan } \\
\text { Pemisahan minyak dan lemak }\end{array}$ & • \\
\hline Perlakuan Primer & $\begin{array}{l}\text { Netralisasi } \\
\text { Koagulasi dan flokulasi } \\
\text { Sedimentasi } \\
\text { Flotasi }\end{array}$ & \\
\hline Perlakuan Sekunder & $\begin{array}{l}\text { Kolam oksidasi } \\
\text { Lokun dan acrasi } \\
\text { Proses lumpur aktif secara konvensional } \\
\text { Modifikasi proses lumpur aktif } \\
\text { Lappered acration } \\
\text { Step acration } \\
\text { Contact stabilization } \\
\text { Hlig rate acration } \\
\text { Oxydation ditch } \\
\text { Iriockling filter } \\
\text { Rotated biological contactor } \\
\text { Fluidized bed }\end{array}$ & - \\
\hline Perlakuan Tersier & $\begin{array}{l}\text { Penyerapan dengan karbon aktif } \\
\text { Pertukaran ion } \\
\text { Nitrifikasi dan denitrifikasi secara biologi } \\
\text { dan tak biologi. } \\
\text { Penapisan ultra } \\
\text { Osmosa - Balik } \\
\text { Elektrodialisis }\end{array}$ & \\
\hline Perlakuan Lumpur & $\begin{array}{l}\text { Pengurangan kandungan air } \\
\text { Insinerasi } \\
\text { Pencerna acrobik } \\
\text { Pencernaan anacrobik }\end{array}$ & \\
\hline
\end{tabular}

III. PERLAKUAN PENDAHULUAN TER HADAP AIR LIMBAH.

Penelitian Pendahuluan pengolahan air limbah secara aerobik dilakukan untuk mengetahui sejauh mana kadar limbah yang sebagai terkandung didalam air limbah dapat diolah dengan cara yang ekonomis. Adapun perlakuan terhadap air limbah yang akan diolah dapat digolongkan sebagai berikut (lihat tabel 2).

Tabel 2 : Perlakuan air limbah sesuai dengan sifat-sifat air limbah

\begin{tabular}{|l|l|l|}
\hline Senyawa Anorganik & $\begin{array}{l}\text { Senyawa gabungan } \\
\text { Perlakuan gabungan }\end{array}$ & Senyalwa organik \\
\hline Perlakuan kimiawi & Perlakuan fisis & Perlakuan biologi \\
Netralisasi & Sedimentasi & Acrasi \\
Koagulasi dan & Penguapan & Pros lumpur aktif \\
flokulasi & Flotasi & konvia inal \\
Oksidasi reduksi & Penapisan & Contacl \\
& Sentrifugasi & stabilization \\
& Penyaringan & Step acration \\
& Insinerasi & Laguna \\
& Pengeringan & Pencernaan aerobik \\
& Penampungan & Pencernaan \\
& & anaerobik \\
& & Desinfeksi \\
\hline
\end{tabular}




\section{METODA PENELITIAN}

Metoda yang digunakan dalam penelitian ini adalah metoda pengolahan air limbah secara aerobik.

IV.1. Peralatan yang digunakan dalam penelitian ini antara lain :

1. Reaktor, dengan kapasitas 3 liter yang di lengkapi dengan :
- bak pengendap

- bak aerasi

- compresor yang dapat menghasilkan udara supaya terjadi aerasi didalam reaktor.

2. Tangki equalisasi/ tangki penampungan yang mempunyai kapasitas penampungan 20 liter. Tangki ini dilengkapi dengan pengaduk dan pendingin yang bersuhu $<10$ ${ }^{\circ} \mathrm{C}$ (agar supaya kandungan air limbah tidak berubah selama proses pengolahan).

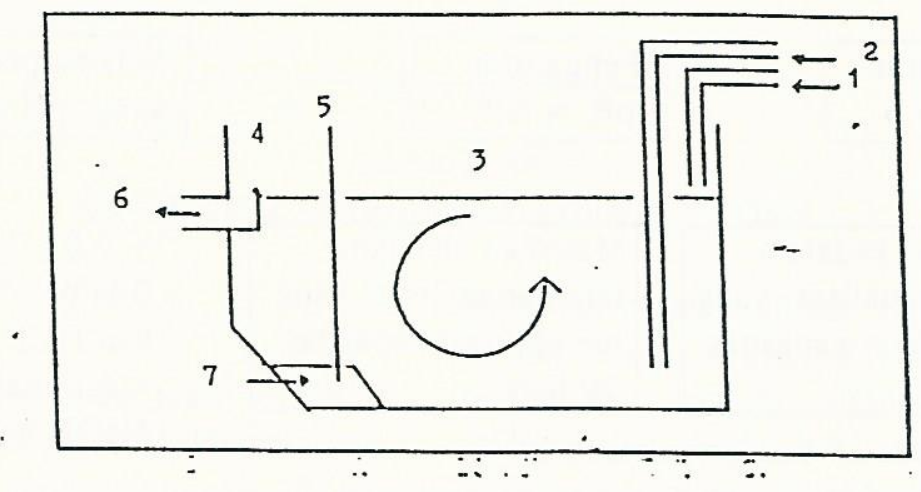

Gambar 1 : Alat Pengolahan Limbah Secara Aerobik.

Keterangan :

$1=$ Influent

2 = Udara

$3=$ bak aerasi

4 = bak pengendapan

$5=$ pembatas antara bak aerasi dan bak pengendapan.

$6=$ effluent

7 = lumpur aktif

\section{IV.2. Tahap-Tahap Penelitian}

1. Influent dan lumpur aktif sebelum diperlakukan diukur $\mathrm{pH}$ nya terlebih dahulu. $\mathrm{pH}$ yang diinginkan untuk influent dan lumpur aktif adalah minimal 6,6 (pada keadaan awal). Setelah Penelitian berlangsung $\mathrm{pH}$ ini harus selalu dikontrol sebagai berikut :

- Pada Reaktor :

Untuk $\mathrm{pH}>7,5$ (basa), harus ditambahkan HCL encer sehingga tercapai pH 7,0 - 7,5.

Untuk $\mathrm{pH}<6$, (asam) harus ditambahkan $\mathrm{NaOH}$ encer sehingga tercapai $\mathrm{pH} 7,0-7,5$.

- Pada Tangki Equalisasi : $\mathrm{pH}$ diusahakan 6,5 - 7,0

2. Untuk selanjutnya perlakuan terhadap influent dan lumpur aktif adalah sebagai berikut : 


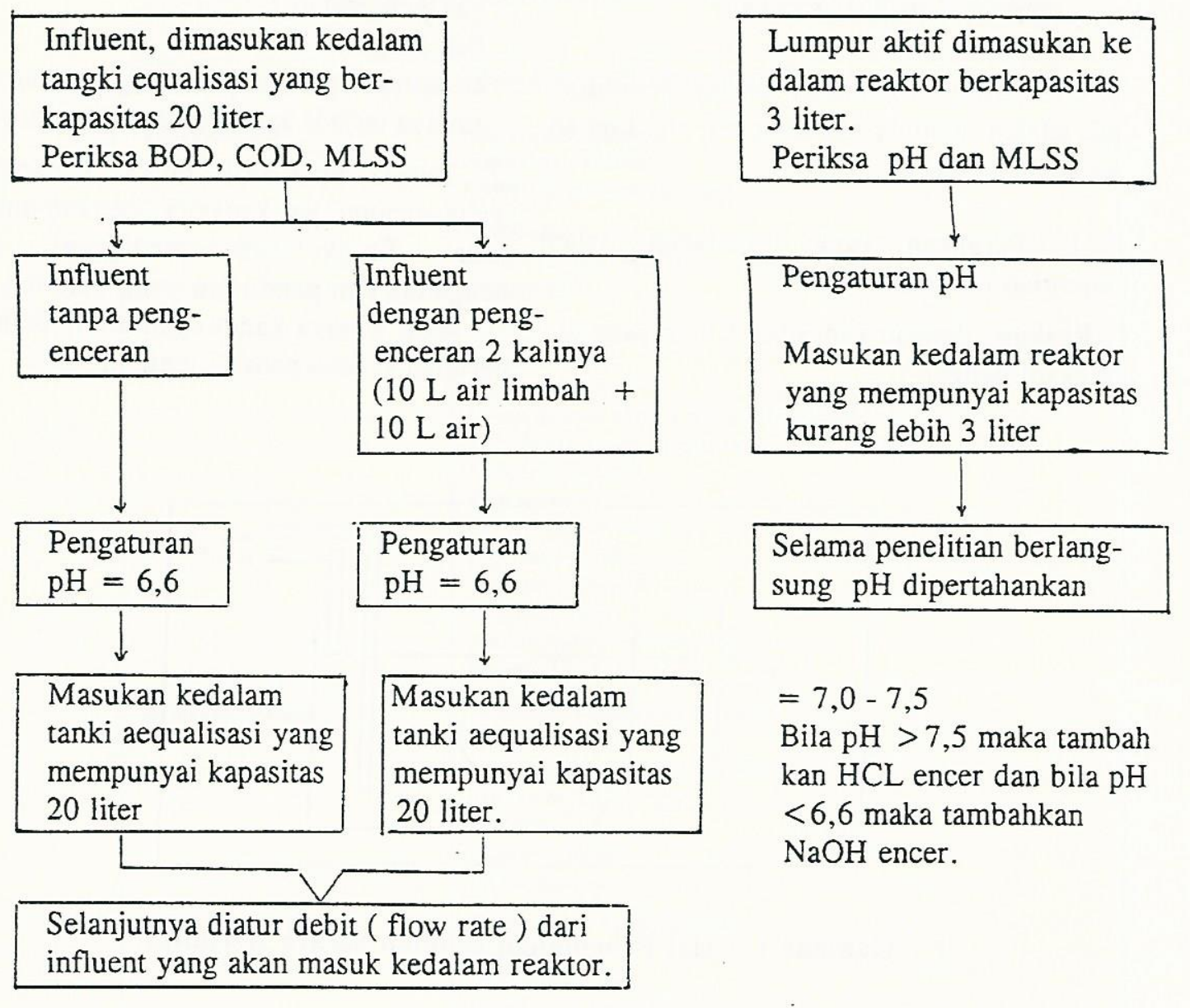

GAMBAR : Diagram alir perlakuan influent.

3. Pengamatan yang dilakukan selama penelitian berlangsung antara lain :

a. Influent, yang harus diperiksa : $\mathrm{pH}$, BOD,COD dan MLSS setiap 2 kali dalam seminggu.

b. Lumpur aktif, yang harus diperiksa : $\mathrm{pH}$, MLSS dan suhu, dilakukan setiap hari. c. Effluent, yang harus diperiksa BOD, $\mathrm{COD}$, setiap 2 hari sekali dengan $\mathrm{pH}$, MLSS diperiksa setiap hari.

d. Masukan data-data tersebut kedalam tabel.

e. Buat grafik effluent tentang :

\section{Grafik COD Vs Hari.}

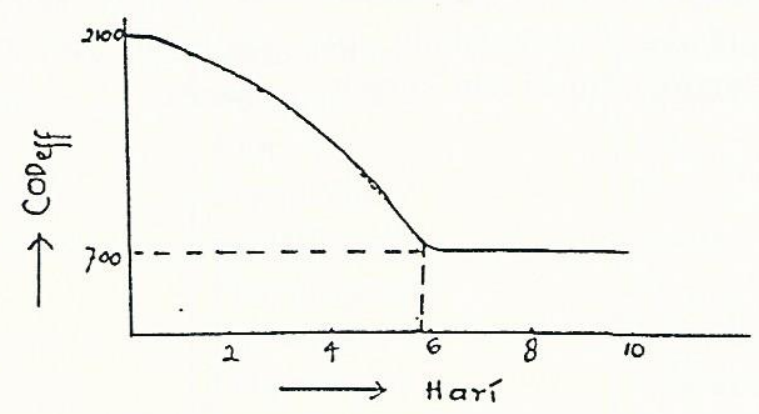

GAMBAR 3 : Grafik COD effluent Vs Hari 
Keterangan :

- Angka 2100 mg / 1 : menunjukan kadar COD dari air limbah pada keadaan awal.

- Angka $700 \mathrm{mg} / \mathrm{l}$ : menunjukan angka yang stabil sampai dengan hari ke 10 , ini berarti bahwa bakteri sudah tidak mampu lagi menurunkan angka $700 \mathrm{mg} / \mathrm{l}$ tersebut (keaktifan bakteri mencapai titik maksimum).

\section{Grafik BOD effluent Vs Hari}

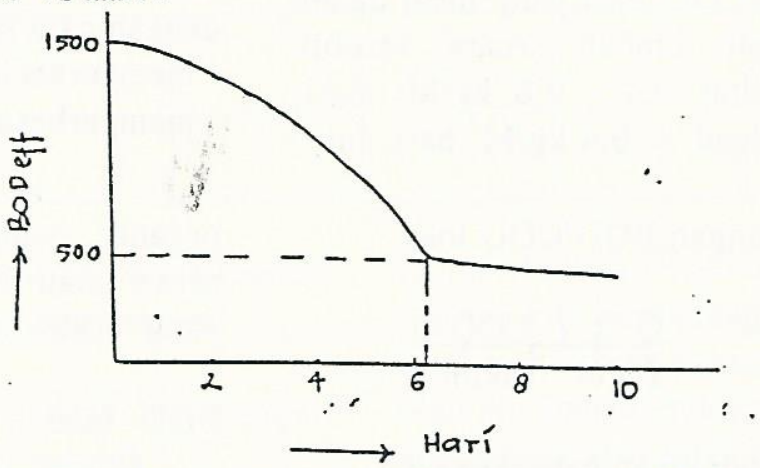

GAMBAR 4 : Grafik BOD effluent Vs Hari

Keterangan :

Dari grafik BOD eff Vs Hari tersebut dapat dihitung $B O D$ removal dengan cara angka BOD tertinggi - angka BOD terendah $=\ldots . \mathrm{mg} / \mathrm{l}$, sehingga $\% \mathrm{BOD}$ removal $=$

BOD $t-B O D r \times 100 \%=$ $\%$ $B O D$ eff $t$

$t=$ Tertinggi. $r=$ Rendah.

Dari Pembuatan grafik COD eff Vs Hari dan BOD eff Vs Hari, maka dapat diketahui sejauhmana keaktifan bakteri secara maksimum dapat mengolah/me nurunkan kandungan BOD/COD dalam pengolahan air limbah tersebut (dapat dilihat dari angka BOD/COD yang terendah). Apabila angka BOD/COD tersebut diatas nilai baku mutu (standard yang ditetapkan) maka harus dicari pemecahannya agar supaya BOD dan COD tersebut memenuhi baku mutu, misalnya dengan cara : penambahan bahan kimia (proses koagulasi dan sedimentasi) atau perlakuan secara fisika.

3. Buat grafik MLSS Vs Hari.

MLSS sebaiknya setiap hari meningkat, ini menandakan bahwa keaktifan bakteri tersebut meningkat atau semakin banyak pertumbuhan bakteri (perkembang biakan bakteri terjadi dengan baik).

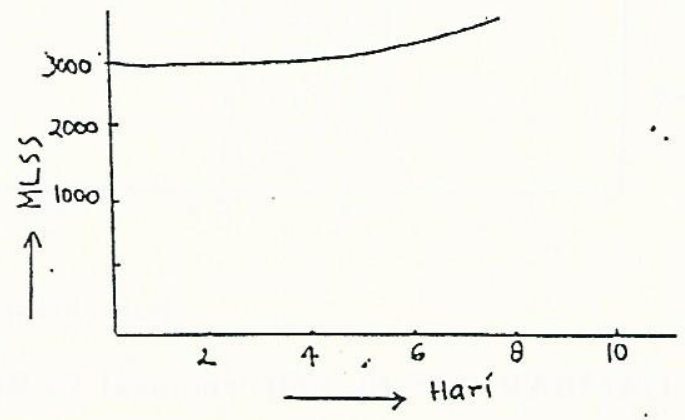

GAMBAR 5 : Grafik MLSS Vs Hari 


\section{f. Hitung BOD/COD load (beban BOD/} COD ).

Maksud penghitungan BOD load adalah adalah untuk mengetahui berapa besar air menanggung beban BOD/COD dalam pengolahan air limbah tersebut.

Adapun BOD/COD load yang ideal dalam pengolahan air limbah secara aerobik umumnya sekitar $0,4-0,6 \mathrm{~kg} / \mathrm{M}^{3}$ hari, apabila BOD load $<0,4 \mathrm{~kg} / \mathrm{M}^{3}$ hari, ini -

Rumus perhitungan BOD/COD load :

COD load $=\frac{\mathrm{Q} \times(\mathrm{COD})}{(\text { Vol. reaktor })}$

COD load menunjukan banyaknya zat menunjukan bakteri kurang aktif dikarenakan kemurangan makanan (bakteri kurus). Dan apabila BOD load $>0,6 \mathrm{~kg} / \mathrm{M}^{3}$.hari , ini menunjukan bahwa bakteri terlalu gemuk sehingga sukar untuk mengadakan aktifitas. Untuk mencapai BOD load yang ideal $(0,4-0,6) \mathrm{kg} / \mathrm{M}^{3}$.hari, dapat dicapai dengan cara sebagai berikut :

- memperkecil debit, Q (flow rate).

- memperbesar volume bak aerasi.

organik yang terkandung dalam bak aerasi atau besarnya beban zat organik yang terkandung dalam MLSS.

$\mathrm{BOD}$ load $=\frac{\mathrm{Q} \times(\mathrm{BOD})}{(\text { Vol. reaktor })}$

g. Buat tabel BOD load dan BOD removal, seperti berikut :

TABEL 3 : BOD load dan BOD removal.

\begin{tabular}{|l|l|l|l|l|l|}
\hline BOD load & & & & & \\
\hline BOD removal & $\%$ & $\%$ & $\%$ & $\%$ & $\%$ \\
\hline
\end{tabular}

h. buat grafik BOD Removal Vs BOD load.

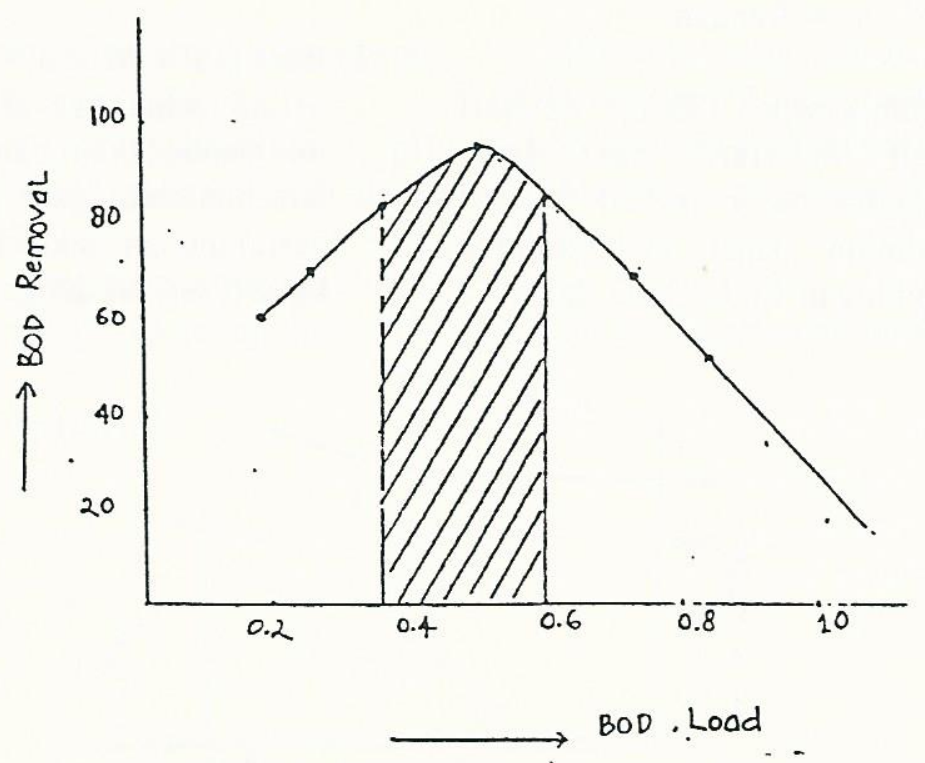

GAMBAR : Grafik BOD removal Vs BOD load. 
Tabel 4 : Contoh Hasil Penelitian Secara Keseluruhan Pemeriksaan awal

\begin{tabular}{|c|c|c|c|c|c|c|}
\hline TANGGAL & \multicolumn{5}{|c|}{ INFLUENT } & \multicolumn{2}{c|}{ LUMPUR AKTIF } \\
\hline & $\mathrm{Ph}$ & $\begin{array}{c}\mathrm{BOD} \\
\mathrm{mg} / \mathrm{l}\end{array}$ & $\begin{array}{c}\mathrm{COD} \\
\mathrm{mg} / \mathrm{l}\end{array}$ & $\begin{array}{c}\mathrm{SS} \\
\mathrm{mg} / \mathrm{l}\end{array}$ & $\mathrm{pH}$ & $\begin{array}{c}\mathrm{SS} \\
\mathrm{mg} / \mathrm{l}\end{array}$ \\
\hline & & & & & & \\
\hline
\end{tabular}

i. Buat tabel hasil penelitian secara keseluruhan selama penelitian berlangsung.

IV.3. Hasil penelitian pendahuluan pengolahan air limbah secara aerobik:

Pada penelitian ini, penyusun mencoba meneliti air limbah rumah tangga yang mempunyai konsentrasi COD sekitar 800$1500 \mathrm{mg} / \mathrm{l}$, namun yang digunakan dalam penelitian ini air limbah rumah tangga yang sudah diencerkan. Untuk tangki - 1 , mempunyai kandungan $\mathrm{COD}$ kurang lebih $600-700 \mathrm{mg} / \mathrm{l}$. dan untuk tangki - 2 mem punyai kandungan COD kurang lebih $350-$ $400 \mathrm{mg} / \mathrm{l}$. pH kedua tangki ini sekitar 6-7, sedangkan konsentrasi MLSS ( SS ) di dalam reaktor adalah sekitar 2000-3000 mg/l Hasil penelitian ini dapat dilihat pada tabel 5, dari tabel ini dapat kita simpulkan bah wa sebaiknya yang perlu diperhatikan pa da keadaan awal dari pengolahan limbah secara aerobik, ini adalah kandungan $\mathrm{ML}$ SS dan kadar BOD yang terkandung da lam air limbah tersebut. Kandungan MLS $S$ perlu kita perhatikan, karena pada MLS $S$ ini terkandung bakteri yang dapat meng olah air limbah, sehingga kita dapat meng etahui baik atau tidak perkembang biakan nya dari bakteri tersebut.

- Jika kadar MLSS belum ada/sedikit pe ningkatannya, ini berarti perkembangbiak an dari bakteri pengolah air limbah belum begitu aktif, sehingga penurunan kadar BOD/COD ( COD removal) pun tidak begitu besar (lihat hasil pengujian no.2).

- Sebaliknya jika pertumbuhan bakteri baik, maka jumlah bakteri dalam reaktor ter sebut akan banyak, sehingga akan meng akibatkan penurunan kadar dari BOD dan COD (COD removal) cukup tinggi (lihat hasil pengujian no.5)

- Namun bila kandungan MLSS sudah terlalu banyak dalam reaktor, maka penurunan kadar BOD/COD (COD removal) akan menurun, ini disebabkan karena terikutsertanya SS kedalam efluent (efluent agak keruh, lihat hasil pengujian no.13). 


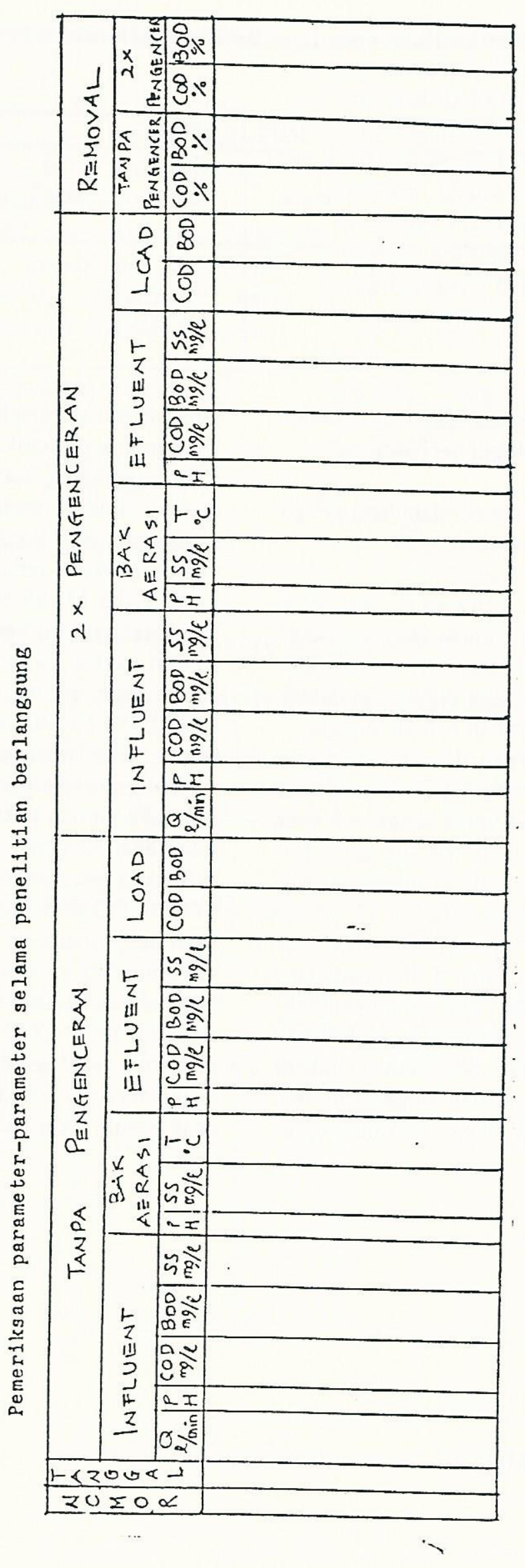




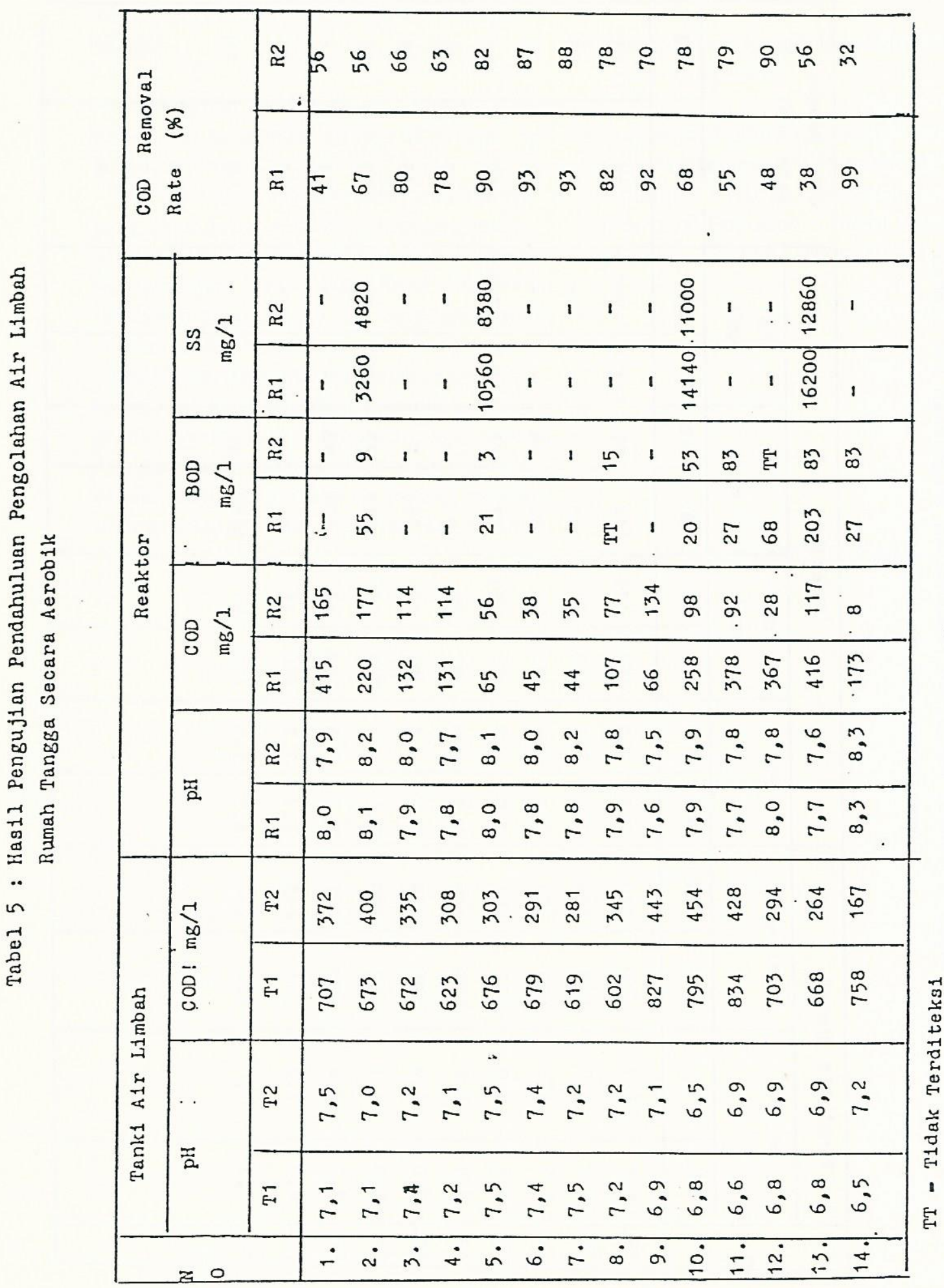




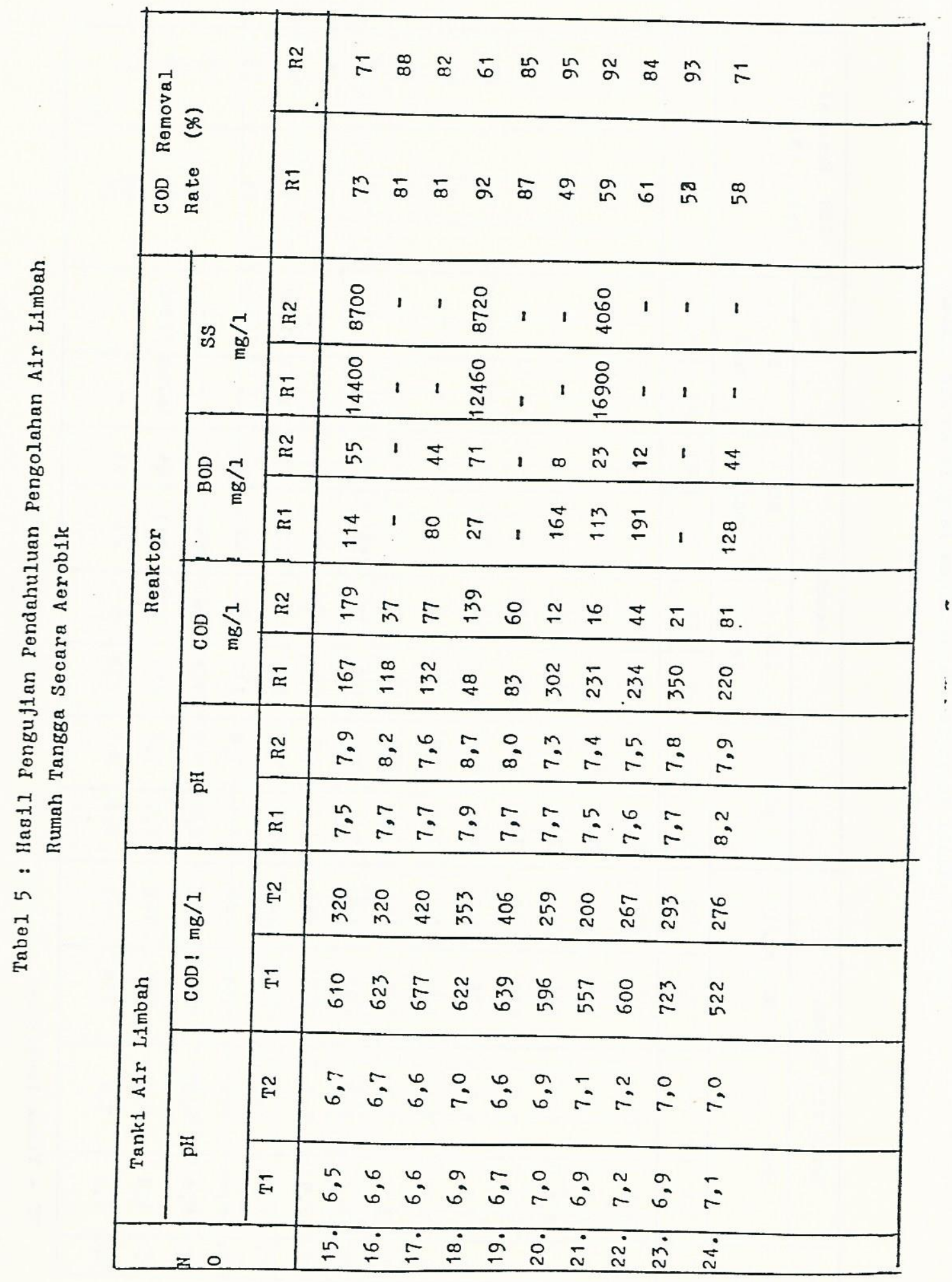




\section{KESIMPULAN}

Dari hasil penelitian pendahuluan ini dapat kami simpulkan bahwa air sebelum diperlakukan, perlu diperhatikan hal-hal sebagai berikut :

- Untuk setiap sample yang digunakan dalam penelitian, parameter tertentu diperiksa keadaan awalnya.

- Tentukan jenis apa sebenarnya air limbah yang akan diolah tersebut (misalnya senyawa organik, senyawa anorganik atau senyawa gabungan), agar supaya dapat ditentukan perlakuan pendahuluan apa yang tepat untuk air limbah tersebut.

- Setelah berlangsung penelitian, segera masukan data kedalam tabel, kemudian dibuat grafik - grafik yang dibutuhkan, agar supaya dari hasil penelitian tersebut akan segera diketahui hasil pengolahan air limbah tersebut, sehingga dapat menentukan langkah selanjut nya.

\section{DAFTAR PUSTAKA}

1. Sistim Pengolahan Limbah Cair Oleh : Dr. Ir. Wibowo MH.Surjowidjojo

2. Dasar-Dasar Pengolahan Air Limbah Oleh : Sugiharto

3. Industrial Pollution Control General Review and Practice in Japan Volume 1: Air and Water Industrial Pollution Control Association of Japan. Tokyo, Japan. 